\title{
Article
}

\section{The Reuse of Industrial By-Products for the Synthesis of Innovative Porous Materials, with the Aim to Improve Urban Air Quality}

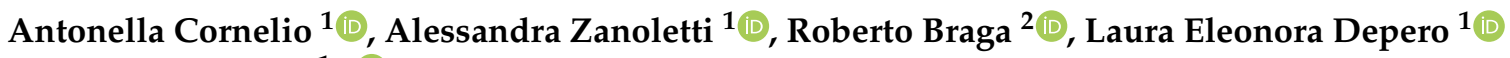 \\ and Elza Bontempi ${ }^{1, *(D)}$ \\ 1 INSTM and Chemistry for Technologies Laboratory, University of Brescia, via Branze 38, 25123 Brescia, Italy; \\ a.cornelio001@unibs.it (A.C.); alessandra.zanoletti@unibs.it (A.Z.); laura.depero@unibs.it (L.E.D.) \\ 2 Dipartimento di Scienze Biologiche Geologiche e Ambientali, Università di Bologna, \\ Piazza di Porta San Donato 1, 40126 Bologna, Italy; r.braga@unibo.it \\ * Correspondence: elza.bontempi@unibs.it
}

check for updates

Citation: Cornelio, A.; Zanoletti, A.; Braga, R.; Depero, L.E.; Bontempi, E. The Reuse of Industrial By-Products for the Synthesis of Innovative

Porous Materials, with the Aim to Improve Urban Air Quality. Appl. Sci. 2021, 11, 6798. https://doi.org/ 10.3390/app11156798

Academic Editor: Mónica Calero de Hoces

Received: 2 July 2021

Accepted: 21 July 2021

Published: 23 July 2021

Publisher's Note: MDPI stays neutral with regard to jurisdictional claims in published maps and institutional affiliations.

Copyright: (c) 2021 by the authors. Licensee MDPI, Basel, Switzerland. This article is an open access article distributed under the terms and conditions of the Creative Commons Attribution (CC BY) license (https:/ / creativecommons.org/licenses/by/ $4.0 /)$.

\begin{abstract}
This works concerns the characterization and the evaluation of adsorption capability of innovative porous materials synthesized by using alginates and different industrial by-products: silica fume and bottom ash. Hydrogen peroxide was used as pore former to generate a porosity able to trap particulate matter (PM). These new materials are compared with the reference recently proposed porous SUNSPACE hybrid material, which was obtained in a similar process, by using silica fume. Structural, morphological, colorimetric and porosimetric analyses were performed to evaluate the differences between the obtained SUNSPACE typologies. The sustainability of the proposed materials was evaluated in terms of the Embodied Energy and Carbon Footprint to quantify the benefits of industrial by-products reuse. Adsorption tests were also performed to compare the ability of samples to trap PM. For this aim, titania suspension, with particles size about $300 \mathrm{~nm}$, was used to simulate PM in the nanoparticle range. The results show that the material realized with bottom ash has the best performance.
\end{abstract}

Keywords: air quality; air pollution; SUNSPACE; PM removal; azure chemistry; circular economy; sustainability; SDG 11; SDG 12

\section{Introduction}

Currently, air pollution is one of the main environmental problems that must be faced at the global level. Different studies reveal that more than $90 \%$ of humans lives in areas subjected to air pollution [1]. Among the air pollutants, particulate matter (PM) causes the greatest concern [2,3]. PM is generated from natural or anthropogenic sources. The first consists mostly of sea salt, mineral dust (typically from deserts) and volcanic particulate [4] and can be achieved by re-suspended dust or mechanical shearing [5], and the second is derived from combustion processes, vehicle emissions, industrial processing or domestic heating [6]. In particular, a higher concentration of PM occurs during winter seasons, due to car traffic and domestic heating when low temperatures and atmospheric stability hinder PM dispersion [7]. It is estimated that PM is responsible for 8.3 million premature deaths in the world in 2017 [8]. One of the most investigated aspects of PM is its dimension, which strongly determines its capability to penetrate the respiratory system. PM can be classified according to its particle size in $\mathrm{PM}_{10}(\leq 10 \mu \mathrm{m}$ aerodynamic diameter $)$ and $\mathrm{PM}_{2.5}(\leq 2.5 \mu \mathrm{m}$ aerodynamic diameter).

The World Health Organization (WHO) reports that long exposure to $\mathrm{PM}_{2.5}$ can generate respiratory and cardiovascular problems [9]. PM is also responsible for diabetes [10], ischemic heart disease and respiratory infection [11]. Moreover, [12] has shown that PM deposition in the respiratory system is higher in the alveolar region followed by the nasal 
and tracheobronchial region. The International Agency for Research on Cancer revealed that $\mathrm{PM}_{2.5}$ is carcinogenic to humans [8].

During the pandemic, PM was considered a possible source of COVID-19 spread [13-16], generating additional concerns for populations living in large cities, which are generally the most polluted in terms of PM concentrations [17].

To reduce its concentration, it is possible to act on PM pollution upstream, by controlling the source emissions, or downstream, by removing the particles by means of chemical methods, dry and wet deposition [18]. Literature reveals that vegetation is one of the most efficient methods for air purification through dry deposition onto leaves [3].

Recently, a new innovative and sustainable porous material called SUNSPACE, "SUstaiNable materials Synthesized from by-Products and Alginates for Clean air and better Environment", has been developed to remove PM from urban areas [19,20]. The importance of this material is twofold: it improves air quality and enables the reuse of industrial by-products.

Economic growth and improved living conditions in the more industrialized countries have led to an increasing demand for goods. This led to large-scale waste production, increasing environmental pollution. The shift from a linear economy to a circular economy marked the turning point. Promoting a more efficient use of resources and recycling, the reuse of wastes allows for the preservation of natural material and reduces landfill disposal [21]. Among the most problematic waste to recycle is industrial waste. It is necessary to ensure that its reuse (for example, after its stabilization) does not create problems for the environment or human health.

In this framework, it is important to highlight that the proposed research activity is in accordance with the SDGs (Sustainable Development Goals), particularly with SDG 11 (Make cities and human settlements inclusive, safe, resilient and sustainable) and SDG 12 (Ensure sustainable consumption and production patterns). Indeed, this work proposes the synthesis and characterization of different SUNSPACE typologies. These new sustainable materials (generated from by-products and waste such as silica fume and bottom ash) are able to increase the resilience of cities [22]. This paper shows an example of circular economy applied in the framework of the Azure Chemistry approach [23].

The original SUNSPACE was synthesized by using silica fume (SF). This by-product is a fine powder (with particle size ranging from 20 to $500 \mathrm{~nm}$ ) derived from ferro-silicon and silicon metal alloy processing. It is commonly used in construction materials, for example, cement, concrete, bricks or ceramics. It is also demonstrated that SF has good performance as a heavy metals stabilizer [24]. Recently, it has been used in the synthesis of porous material to PM capture $[19,20]$. The color of silica can change from light to dark grey as a function of the manufacturing process, considering for example, the composition of starting materials, the combustion temperature and the obtained final products [25]. Silica fume used in SUNSPACE synthesis is dark grey. The dark color represents an esthetic limit if the idea is to apply SUNSPACE as plaster on wall or as rooftiles. To overcome this problem, another industrial by-product, bottom ash (BA), was recently proposed for material synthesis and is mainly used with the goal of obtaining a lightcolored material [20].

BA is the residue of municipal solid waste incineration (MSWI). It is estimated that BA represents $90 \%$ of solid residues generated in incineration plants [21]. Twenty million tons of BA are produced every year in Europe [26]. BA is not considered hazardous waste (2008/98/CE); it contains heavy metal with low volatilization.

Assi et al. revealed that fine fraction of BA (lower than 300 microns) is characterized by a higher leaching concentration of heavy metals, such as $\mathrm{Pb}$ and $\mathrm{Zn}$, compared to coarse fraction (more than 1400 microns) [27]. The chemical composition of these ashes (high amount of $\mathrm{Al}, \mathrm{Si}, \mathrm{Ca}$ and $\mathrm{Fe}$ ) makes them suitable mainly for cement production [28]. Recent work shows the possibility to use BA as a stabilizer agent for fly ash derived from the same incineration process [29]. BA is also used as adsorbent material due to high porosity for heavy metal wastewater treatments [30]. 
Moreover, another improvement has been introduced in this work. For the first time, hydrogen peroxide was used instead of sodium bicarbonate as a pore former to avoid thermal treatment. This allows for the simplification of the application of materials as plaster and then increases the material sustainability.

Structural, morphological, colorimetric and porosimetric analyses of all SUNSPACE typologies were performed. Additionally, adsorption tests were made to compare the ability of all samples to trap PM.

\section{Materials and Methods}

\subsection{Materials and Reagents}

Calcium iodate $\left(\mathrm{Ca}\left(\mathrm{IO}_{3}\right)_{2}\right.$, CAS number: 7789-80-2,) sodium alginate (SA, CAS number: 9005-38-3, viscosity $\mathrm{c}=1 \%$ water at $\left.25^{\circ} \mathrm{C} 5.0-40.0 \mathrm{cps}\right)$, sodium bicarbonate $\left(\mathrm{NaHCO}_{3}\right.$, CAS number $14455-8, \geq 99.8 \% w / w)$ and hydrogen peroxide $\left(\mathrm{H}_{2} \mathrm{O}_{2}\right.$, CAS number $7722-84-1$, $30 \% w / w)$ were bought from Sigma Aldrich (St. Louis, Missouri, USA).

Silica fume was kindly provided by Metalleghe spa (Brescia, Italy). Bottom ash, derived from a municipal solid waste incineration plant, and calcium hydroxide were handled by A2A spa. Titanium dioxide powder (Hombitan 97\% with $300 \mathrm{~nm}$ size) was kindly supplied by Rifra Masterbatches spa (Molinetto di Mazzano, Brescia, Italy).

MilliQ water (Millipore DirectQ-5 purification system) was used for the preparation of porous materials.

\subsection{Materials Characterization}

Ces Selector software [31] was used to assess the environmental impact of porous materials in terms of the Embodied Energy and Carbon Footprint.

The evaluation of PM entrapment was performed by a total reflection X-ray fluorescence (TXRF) spectrophotometer equipped with Mo anode (S2 PICOFOX, Bruker AXS Microanalysis GmbH (Berlin, Germany)) operating at $750 \mathrm{~A}$ and $50 \mathrm{kV}$. Titania aerosol was generated by Grimm aerosol, Particle-Generator MODEL 7.811.

Structural analysis on porous samples was performed by X-ray-diffraction (XRD) with a Panalytical $X^{\prime}$ Pert Pro diffractometer equipped with the $X^{\prime}$ Celerator detector and $\mathrm{Cu}$ anode (CuKalpha $1.5406 \mathrm{~A}$ ) operating at $40 \mathrm{KV}$ and $40 \mathrm{~mA}$. The pattern was collected between $10^{\circ}$ and $70^{\circ}$ (in 2theta).

The color variation between samples was evaluated using a spectrophotometer (CM2600d Minolta).

Samples were digested following the EPA method 3052 for siliceous matrices [32] using $4 \mathrm{~mL}$ of $\mathrm{HNO}_{3}(\geq 65 \%), 2 \mathrm{~mL}$ of $\mathrm{HCl}(37 \%)$ and $2 \mathrm{~mL}$ of $\mathrm{HF}(48 \%)$. The volume of each digested sample was adjusted to $50 \mathrm{~mL}$ using MilliQ water.

To quantify the $\mathrm{TiO}_{2}$ concentration, an internal standard $\mathrm{Ga}(1 \mathrm{mg} / \mathrm{L})$ was added to the digested samples. Ten microliters of this solution were deposited onto a plexiglass circular support and dried. The choice to use plexiglass support instead of quartz is due to the HF adoption in digestion process. Three specimens for each sample were performed. Finally, the spectra evaluation was executed by Spectra Plus 5.3 (Bruker AXS Microanalysis $\mathrm{GmbH}$, Berlin, Germany).

The accessible porosity and pore size distribution were quantified using a Pascal 240 Mercury Porosimeter from Thermo Scientific, capable of intruding mercury by a stepwise increase of pressure from vacuum to $200 \mathrm{MPa}$. After drying at $60{ }^{\circ} \mathrm{C}$ for $12 \mathrm{~h}$, a broken piece of each sample of about $1 \times 1 \mathrm{~cm}$ size was tested. The volume change of mercury between each pressure step gives a number of parameters, of which the pore size distribution, the accessible porosity, the mode, mean and median pore size values were evaluated from the results. 


\subsection{Samples Preparation}

Six samples were synthetized by different industrial by-products (silica fume or bottom ash). The composition of each sample, expressed in g except for hydrogen peroxide expressed in $\mathrm{mL}$, is reported in Table 1.

Table 1. Composition of porous samples. Samples 1, 5 and 6 were synthetized by silica fume, while samples 2, 3 and 4 were synthesized by bottom ash.

\begin{tabular}{cccccccc}
\hline & $\begin{array}{c}\text { Silica Fume (SF) } \\
(\mathbf{g})\end{array}$ & $\begin{array}{c}\text { Bottom Ash (BA) } \\
(\mathbf{g})\end{array}$ & $\begin{array}{c}\mathrm{Ca}(\mathrm{OH})_{2} \\
(\mathrm{~g})\end{array}$ & $\begin{array}{c}\mathrm{NaC}_{6} \mathrm{H}_{7} \mathrm{O}_{6} \\
(\mathrm{~g})\end{array}$ & $\begin{array}{c}\mathrm{Ca}\left(\mathrm{IO}_{3}\right)_{2} \\
(\mathrm{~g})\end{array}$ & $\begin{array}{c}\mathrm{NaHCO}_{3} \\
(\mathrm{~g})\end{array}$ & $\begin{array}{c}\mathrm{H}_{2} \mathrm{O}_{2} \\
(\mathrm{~mL})\end{array}$ \\
\hline Sample 1 & 17.88 & - & - & 0.6 & 1 & 5 & - \\
Sample 2 & - & 9 & 9 & 0.6 & 1 & 5 & - \\
Sample 3 & - & 9 & 9 & - & - & - & 7.2 \\
Sample 4 & - & 9 & 9 & - & - & - & 5.4 \\
Sample 5 & 17.88 & - & - & 0.6 & 1 & - \\
Sample 6 & 17.88 & - & - & 0.6 & 1 & - \\
\hline
\end{tabular}

First, BA was dried for $1 \mathrm{~h}$ at $100{ }^{\circ} \mathrm{C}$ to eliminate moisture and then sieved to obtain a fine powder with a size dimension lower than $300 \mu \mathrm{m}$. Sample 1 and sample 2 were synthetized according to [20]. Sodium alginate and calcium iodate (used as a cross linker) were mixed vigorously with MilliQ water. Then, silica fume (sample 1) or bottom ash and calcium hydroxide, in the same proportion (sample 2), were added to the compound. Finally, sodium bicarbonate (as pore former) was added. The slurry obtained was put on a heating plate for $1 \mathrm{~h}$ at a low temperature $\left(70 / 80^{\circ} \mathrm{C}\right)$ to allow for pore generation due to sodium bicarbonate decomposition.

To avoid the thermal treatment, sodium bicarbonate was replaced with hydrogen peroxide in the synthesis process of samples $3,4,5$ and 6 . Sample 3 was performed by mixing $9 \mathrm{~g}$ of bottom ash, $9 \mathrm{~g}$ of calcium hydroxide, $7.2 \mathrm{~mL}$ of hydrogen peroxide and $9 \mathrm{~mL}$ of MilliQ water. The amorphous phase of BA is expected to react with hydrogen peroxide to promote pozzolanic reaction [33], which favors the formation of a stable material. Sample 4 is characterized by a lower quantity of hydrogen peroxide $(5.4 \mathrm{~mL})$ compared to sample 3 . Sample 5 was synthetized by mixing vigorously $20 \mathrm{~mL}$ of MilliQ water, $0.6 \mathrm{~g}$ of sodium alginate and $1 \mathrm{~g}$ of calcium iodate until a gel is formed. Then, $17.88 \mathrm{~g}$ of silica fume and $7.2 \mathrm{~mL}$ of hydrogen peroxide were added. Sample 6 contains a lower quantity of hydrogen peroxide $(5.4 \mathrm{~mL})$. After the synthesis, all samples were left at room temperature for 1 week to reach the final consolidation. Figure 1 shows the images of all samples after consolidation.

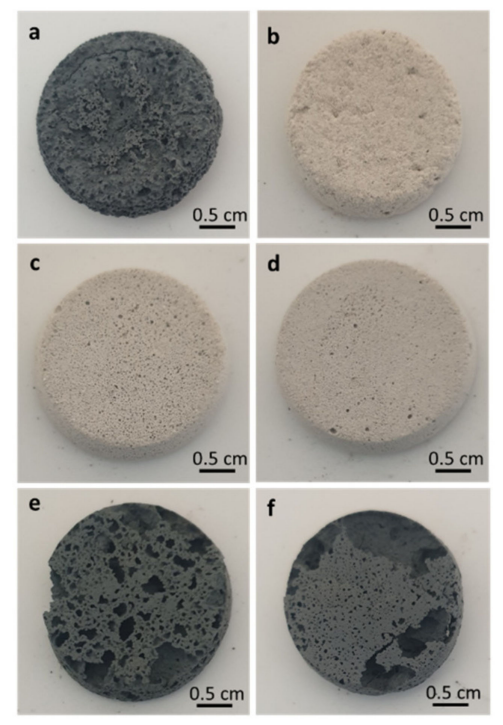

Figure 1. Images of samples synthetized with silica fume $(\mathbf{a}, \mathbf{e}, \mathbf{f})$ and with bottom ash $(\mathbf{b}-\mathbf{d})$. 


\section{Results and Discussion}

\subsection{Sample Sustainability}

The sustainability analysis of all samples was evaluated in terms of the Embodied Energy (EE) and Carbon Footprint (CF) [34-37]. The bottom ash pre-treatment and the thermal treatment on a heating plate at a low temperature $\left(70 / 80^{\circ} \mathrm{C}\right)$, to which some samples were subjected, was considered in the evaluations. In Figure 2, the EE (MJ/kg) versus $\mathrm{CF}(\mathrm{kg} / \mathrm{kg})$ of six samples is reported. All samples appear to be more sustainable compared to materials commonly used in the filter production such as polypropylene (PP), polyethylene (PE), polyamide (PA) and polystyrene (PS). The samples' sustainability can be compared with building materials such as brick, Portland cement and concrete due to the idea to propose SUNSPACE use in construction. The graph shows that sample 1 has lower EE, while samples 5 and 6 are more sustainable in terms of $\mathrm{CO}_{2}$ emissions compared to other samples. The higher EE and CF resulting for samples 2, 3 and 4 can be attributed to the use of BA instead of SF in their synthesis. In particular, no pre-treatment is necessary for silica fume before its reuse. Instead, BA was subjected to a thermal treatment, to reduce its moisture, to control the amount of water that was added (see Table 1) and to guarantee the sample's workability during the synthesis. However, in the future, it may also be possible to find more sustainable BA pre-treatment to increase the sustainability of its use.

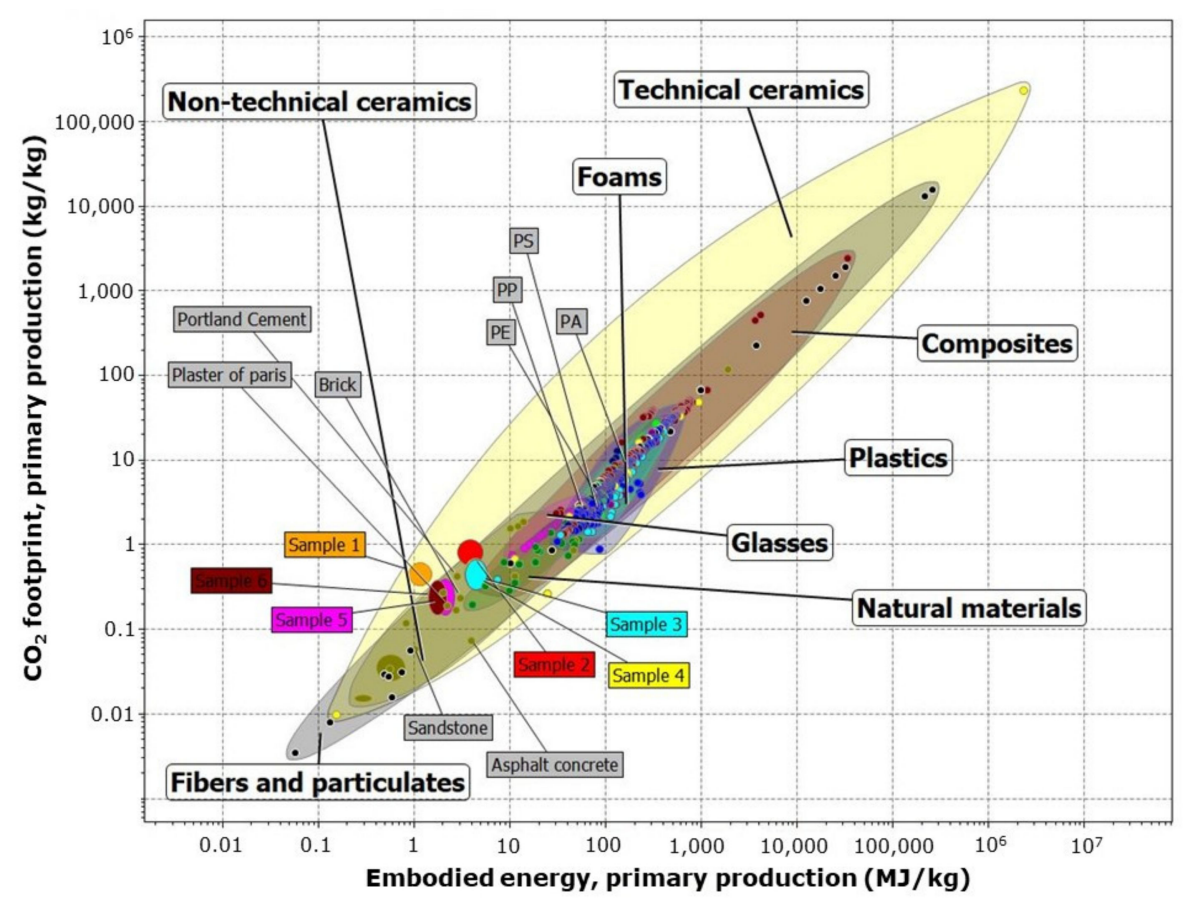

Figure 2. Sustainability analysis of all six samples in terms of the Embodied Energy (EE) and Carbon Footprint (CF).

\subsection{Sample Colorimeter}

BA is used instead of SF with the aim to lighten the porous material, as shown in Figure 1. Colorimetric analysis allows for the definition of a color with CIELAB coordinates: $\mathrm{L}$ (luminance) and two colors channel ( $\mathrm{a}$ and $\mathrm{b}$ ). L values are presented between 0 (dark) and 100 (white), while $a$ and $b$ are presented between negative and positive values. Negative values represent green and blue colors, while positive values are red and yellow for a and $\mathrm{b}$, respectively. Table 2 shows the results of colorimetric analysis of all samples. It is evident that the colors are very different. Indeed, samples synthetized with SF (samples 1, 5 and 6) have lower $\mathrm{L}$ values $(38.83<\mathrm{L}<47.46)$ compared with samples obtained starting from BA (samples 2, 3 and 4) $(81.97<\mathrm{L}<86.01)$. 
Table 2. Colorimetric analysis of all samples. Data found including (SCI) and excluding (SCE) specular component.

\begin{tabular}{ccccccc}
\hline \multirow{2}{*}{ Samples } & \multicolumn{3}{c}{ SCI } & \multicolumn{3}{c}{ SCE } \\
\cline { 2 - 6 } & $\mathbf{L}$ & $\mathbf{a}$ & $\mathbf{b}$ & $\mathbf{L}$ & $\mathbf{a}$ & $\mathbf{b}$ \\
\hline Sample 1 & $38.83 \pm 0.01$ & $-0.92 \pm 0.01$ & $-2.33 \pm 0.01$ & $39.61 \pm 0.01$ & $-0.89 \pm 0.02$ & $-2.36 \pm 0.01$ \\
Sample 2 & $81.97 \pm 0.01$ & $0.77 \pm 0.01$ & $6.34 \pm 0.01$ & $81.49 \pm 0.01$ & $0.80 \pm 0.01$ & $6,22 \pm 0.01$ \\
Sample 3 & $86.32 \pm 0.01$ & $0.16 \pm 0.01$ & $3.13 \pm 0.01$ & $85.86 \pm 0.01$ & $0.21 \pm 0.01$ & $3.03 \pm 0.02$ \\
Sample 4 & $86.01 \pm 0.01$ & $0.21 \pm 0.01$ & $3.41 \pm 0.01$ & $85.82 \pm 0.01$ & $0.26 \pm 0.10$ & $3.31 \pm 0.01$ \\
Sample 5 & $46.69 \pm 0.39$ & $0.63 \pm 0.02$ & $0.76 \pm 0.24$ & $46.45 \pm 0.39$ & $0.59 \pm 0.02$ & $0.83 \pm 0.24$ \\
Sample 6 & $47.46 \pm 0.52$ & $0.81 \pm 0.02$ & $1.46 \pm 0.06$ & $47.21 \pm 0.51$ & $0.78 \pm 0.01$ & $1.53 \pm 0.07$ \\
\hline
\end{tabular}

\subsection{Structural Analysis}

An XRD analysis of samples 1 (SUNSPACE) and 2 (SUNSPACE with BA) is reported in previous work [20]. In Figure 3, the XRD patterns of samples 3, 4, 5 and 6 are shown. Samples 3 and 4 show similar patterns. The identified crystalline phases are calcium carbonate $\left(\mathrm{CaCO}_{3}\right)$ and quartz $\left(\mathrm{SiO}_{2}\right)$, both predominant in bottom ash powder [29], and calcium hydroxide $\left(\mathrm{Ca}(\mathrm{OH})_{2}\right)$ used in the material synthesis. Moreover, calcium carbonate is also probably formed during the carbonation reaction between calcium hydroxide and $\mathrm{CO}_{2}$, as already extensively discussed in literature [38-41]. Some peaks can be attributed to aluminum silicate hydroxide chloride. From this analysis, it is possible to conclude that the hydrogen peroxide concentration does not seem to involve structural changes in the samples. Additionally, samples 5 and 6 show similar XRD patterns. They are characterized by the presence of a large halo (between $15^{\circ}$ and $30^{\circ}$ in 2theta), that can be attributed to an amorphous phase due to the presence of silica fume, which is an amorphous material $[17,24,42,43]$. Furthermore, cristobalite $\left(\mathrm{SiO}_{2}\right)$ and lautarite $\left(\mathrm{Ca}\left(\mathrm{IO}_{3}\right)_{2}\right)$ peaks are identified. Calcium iodate is used in the synthesis of these samples.

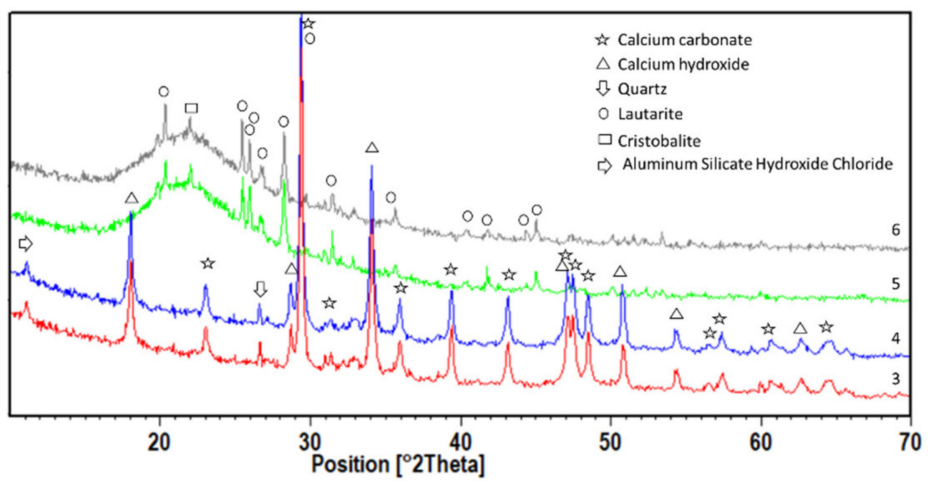

Figure 3. XRD patterns of samples 3, 4, 5 and 6.

\subsection{Morphological Analysis}

Figure 4 shows the optical microscopy of samples 1 (a), 2 (b), 3 (c), 4 (d), 5 (e) and 6 (f). All samples show a visible porosity. The main differences concern the shape and size of the pores. Sample 1 reveals the presence of macro-porous between 100 and $200 \mu \mathrm{m}$, while sample 2 is characterized by pores with sizes up to $1 \mathrm{~mm}$. Sample 3 shows a highly porous surface, rich in circular pores. The larger pores have a diameter of about $300 \mu \mathrm{m}$. The morphology of sample 4 is similar to that of the previous one, but there are some larger pores. This is probably correlated to the lower amount of pore former used for the synthesis of this sample. Samples with SF present pores with irregular shapes and dimensions of about 100-200 $\mu \mathrm{m}$ (sample 5) and $500 \mu \mathrm{m}$ (sample 6).

\subsection{Porosimetric Analysis}

The pore size distributions of samples are shown in Figure 5, while Table 3 summarizes the basic descriptive statistics. 


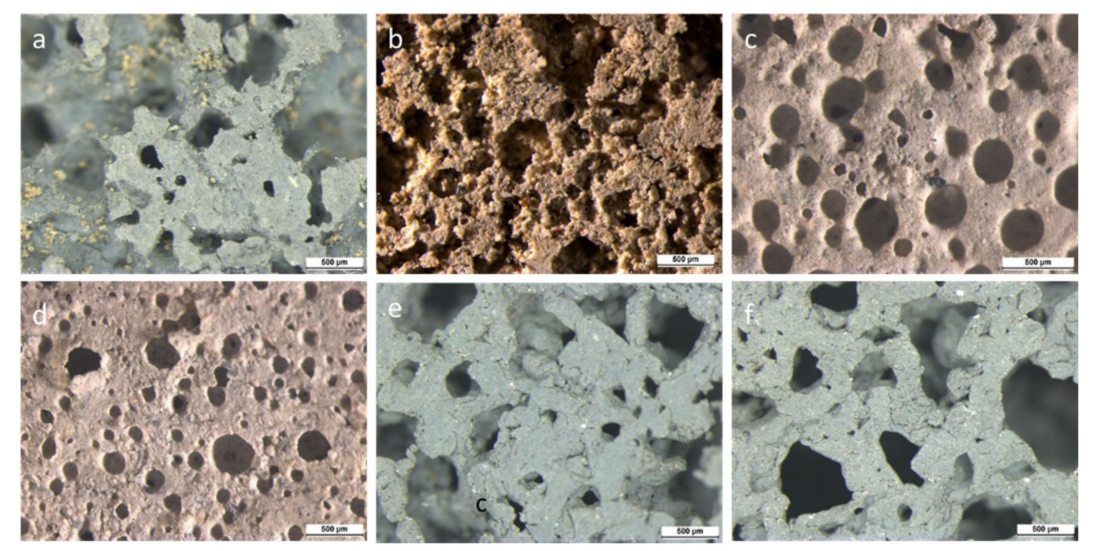

Figure 4. Optical microscopy images of samples sythetized with silica fume: sample 1 (a), 5 (e) and 6 (f) and bottom ash: sample 2 (b), sample 3 (c) and 4 (d).
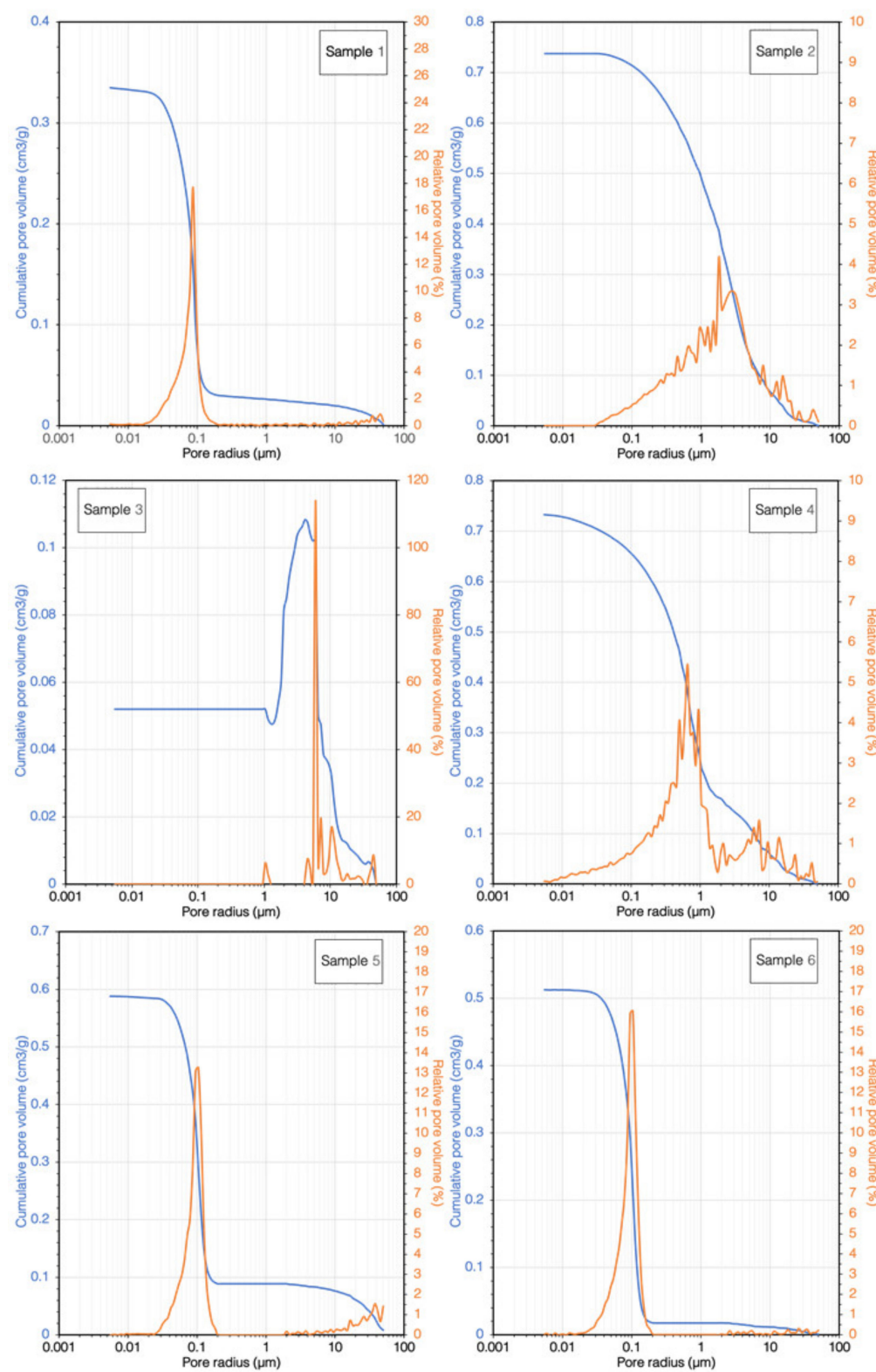

Figure 5. Pore size distributions of all six samples quantified by mercury porosimetry analysis. 
Table 3. Results from mercury intrusion porosimetry.

\begin{tabular}{ccccc}
\hline Sample & $\begin{array}{c}\text { Accessible } \\
\text { Porosity } \\
\mathbf{( \% )}\end{array}$ & $\begin{array}{c}\text { Average Pore } \\
\text { Radius }(\mu \mathrm{m})\end{array}$ & $\begin{array}{c}\text { Median Pore } \\
\text { Radius }(\mu \mathrm{m})\end{array}$ & $\begin{array}{c}\text { Modal Pore } \\
\text { Radius }(\mu \mathrm{m})\end{array}$ \\
\hline 1 & 41.1 & 0.0356 & 0.0777 & 0.0849 \\
2 & 63.2 & 0.0282 & 1.7808 & 1.7938 \\
3 & 3.4 & 0.0141 & 9.6896 & 5.6504 \\
4 & 58.1 & 0.0387 & 0.6153 & 0.6127 \\
5 & 51.6 & 0.0418 & 0.0954 & 0.1058 \\
6 & 49.1 & 0.0455 & 0.0911 & 0.1063 \\
\hline
\end{tabular}

The accessible porosity by intrusion is always above $41 \%$, with a maximum of $63 \%$ for the sample 2 . The anomalously low value for sample 3 (about $3 \%$ accessible porosity), which is clearly at odds with the morphological observations, indicates sample deformation and porosity collapse during the test. The sample 3 is therefore not considered in the mercury porosimetry results.

The pore sizes of the samples 1, 5 and 6, all of which were prepared with SF, follow a unimodal distribution with a pore radius mode of $0.08-0.1 \mu \mathrm{m}$. The sample 4 shows a bimodal pore size distribution, with a main peak at about $0.65 \mu \mathrm{m}$ and a secondary peak related to larger pores with a radius of about $7-8 \mu \mathrm{m}$. Finally, the pore size distribution of sample 2 spans about an order of magnitude, with a mode of $1.79 \mu \mathrm{m}$.

\subsection{Sample PM Capability}

The performance in PM trapping of SUNSPACE and SUNSPACE synthesized by using BA was evaluated in previous work [20]. In this paper, these values were compared with samples $3,4,5$ and 6 .

To evaluate the adsorption capacity of these porous materials, three samples of each material were exposed to a $\mathrm{TiO}_{2}$ suspension with size dimension of $300 \mathrm{~nm}, 3 \mathrm{~g} / \mathrm{L}$. The suspension was prepared according to [20] and then sprayed using Grimm aerosol nanoparticle generator. The same experimental set up of [20] was performed. Samples were exposed for $4 \mathrm{~min}$, after $1 \mathrm{~min}$ of stabilization.

To evaluate the amount of trapped $\mathrm{TiO}_{2}$ by each specimen, pristine and exposed samples were compared. They were scraped to obtain $0.25 \mathrm{~g}$ of powder from each sample for chemical analysis. For this aim, samples were digested according to the procedure reported in the experimental section. The Ti concentration $(\mathrm{mg} / \mathrm{L})$ was evaluated by TXRF analysis and then converted to $\mathrm{TiO}_{2}$ expressed in $\mathrm{mg} / \mathrm{kg}$.

Figure 6 shows the comparison between pristine and exposed samples synthetized by BA (Figure 6a) (sample 3 and 4 ) and SF (Figure 6b) (sample 5 and 6). The results show that pristine materials always present a titania amount lower than that of corresponding materials, which were subjected to titania flux.

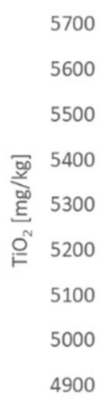

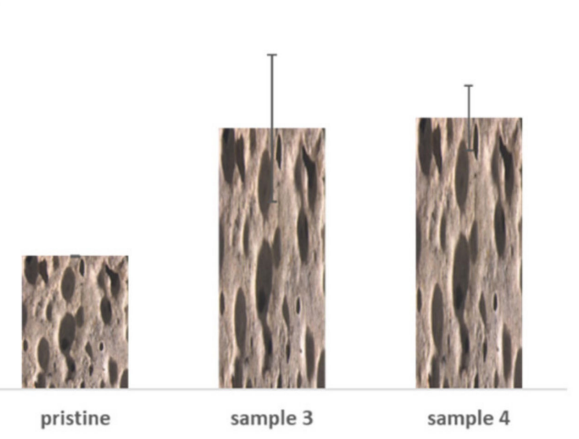

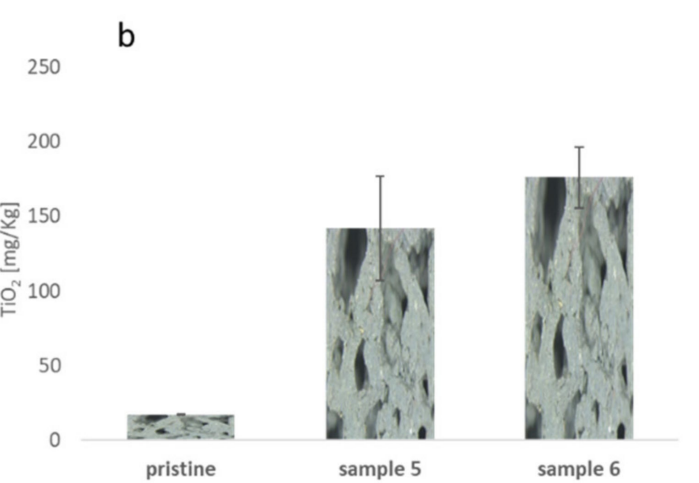

pristine

sample 5

sample 6

Figure 6. Amount of $\mathrm{TiO}_{2}$ concentration on SUNSPACE samples synthetized by (a) bottom ash (samples 3 and 4) and (b) silica fume (samples 5 and 6). Pristine samples were not in contact with titania nanoparticles. The other samples were exposed to $\mathrm{TiO}_{2}$. 
It is also apparent that the pristine samples synthetized with BA are characterized by a higher concentration of titania than those generated with SF. Indeed, as reported in the literature, BA is characterized by titania (about $1 \%$ wt) $[27,28,44,45]$.

Using both using BA and SF, samples 4 and 6 (characterized by a lower hydrogen peroxide concentration) obtained good results despite their different pore structure. Sample 4 is characterized by a bimodal pore size distribution. The presence of interconnected pores with sizes more than $1 \mu \mathrm{m}$ suggests an open structure that favors the uptake of PM. Sample 6 shows a uniform structure, with pores of a lower dimension (about $0.1 \mu \mathrm{m}$ ). The graph shows that sample 4 seems to have the best performance. High concentrations of $\mathrm{TiO}_{2}$ (about $300 \mathrm{mg} / \mathrm{kg}$ ) penetrated into its porous surface.

\section{Conclusions}

This work shows a comparison of innovative porous materials synthetized by bottom ash and silica fume (as raw materials) to promote circular economy and new solutions to improve urban air quality. Some variations in the synthesis process were performed in the framework of the Azure chemistry approach. The use of hydrogen peroxide instead of sodium bicarbonate circumvented the heating process. This simplifies the synthesis process and, consequently, the application of material as plaster. All of the samples were characterized by structural, morphological, porosimetric and colorimetric analyses. The use of BA results in a lighter-colored material than the one realized with SF. Samples realized by SF and BA show different porous structures. The materials synthetized by SF are characterized by smaller pore sizes $(0.08-0.1 \mu \mathrm{m})$ than those made with BA $(0.65-8 \mu \mathrm{m})$. The porous materials investigated in this work were designed to reduce PM concentrations, so an adsorption capacity test was carried out. According to the results, sample 4 (synthetized with bottom ash) shows the best performance. For the future, some variation in the BA treatment will be considered to promote the sustainability of the material.

Author Contributions: Conceptualization, A.C., A.Z. and E.B.; software, A.Z.; formal analysis, A.C. and A.Z.; investigation, A.C., A.Z. and R.B.; data curation, A.C. and A.Z.; writing-original draft preparation, A.C., A.Z., R.B. and E.B.; writing-review and editing, L.E.D. and E.B.; supervision, E.B.; project administration, L.E.D. and E.B.; funding acquisition, L.E.D. and E.B. All authors have read and agreed to the published version of the manuscript.

Funding: This research was conducted in the framework of the RENDERING project: "Energy recovery of waste sludge and their re-use as an alternative to some natural resources, for the production of Green composites", funded by Ministero dell'Ambiente e della Tutela del Territorio e del Mare-Direzione generale dei rifiuti e dell'inquinamento. It is supported by the University of Brescia, CSMT, INSTM and Regione Lombardia.

Institutional Review Board Statement: Not applicable.

Informed Consent Statement: Not applicable.

Data Availability Statement: Data is contained within the article.

Acknowledgments: Fausto Peddis (Dip. Di Ingegneria Civile, Chimica, Ambientale e dei materialiDICAM).

Conflicts of Interest: The authors declare no conflict of interest.

\section{References}

1. Wei, Z.; Su, Q.; Yang, J.; Zhang, G.; Long, S.; Wang, X. High-performance filter membrane composed of oxidized Poly (arylene sulfide sulfone) nanofibers for the high-efficiency air filtration. J. Hazard. Mater. 2021, 417, 126033. [CrossRef] [PubMed]

2. Domingo, J.L.; Rovira, J. Effects of air pollutants on the transmission and severity of respiratory viral infections. Environ. Res. 2020, 187, 109650. [CrossRef]

3. Przybysz, A.; Nersisyan, G.; Gawroński, S.W. Removal of particulate matter and trace elements from ambient air by urban greenery in the winter season. Environ. Sci. Pollut. Res. 2019, 26, 473-482. [CrossRef]

4. Gieré, R.; Querol, X. Solid particulate matter in the atmosphere. Elements 2010, 6, 215-222. [CrossRef] 
5. Zanoletti, A.; Bilo, F.; Federici, S.; Borgese, L.; Depero, L.E.; Ponti, J.; Valsesia, A.; La Spina, R.; Segata, M.; Montini, T.; et al. The first material made for air pollution control able to sequestrate fine and ultrafine air particulate matter. Sustain. Cities Soc. 2020, 53, 101961. [CrossRef]

6. Juda-Rezler, K.; Reizer, M.; Oudinet, J.-P. Determination and analysis of PM10 source apportionment during episodes of air pollution in Central Eastern European urban areas: The case of wintertime. Atmos. Environ. 2011, 45, 6557-6566. [CrossRef]

7. Majewski, G.; Kleniewska, M.; Brandyk, A. Seasonal variation of particulate matter mass concentration and content of metals. Pol. J. Environ. Stud. 2011, 20, 417-427.

8. Wu, X.; Zhu, B.; Zhou, J.; Bi, Y.; Xu, S.; Zhou, B. The epidemiological trends in the burden of lung cancer attributable to PM2.5 exposure in China. BMC Public Health 2021, 21, 1-8. [CrossRef] [PubMed]

9. Cui, J.; Wang, Y.; Lu, T.; Liu, K.; Huang, C. High performance, environmentally friendly and sustainable nanofiber membrane filter for removal of particulate matter 1.0. J. Colloid Interface Sci. 2021, 597, 48-55. [CrossRef]

10. Heck, T.G.; Fiorin, P.B.G.; Frizzo, M.N.; Ludwig, M.S. Fine particulate matter (PM2.5) air pollution and type 2 diabetes mellitus (T2DM): When experimental data explains epidemiological facts. Diabetes Its Complicat. 2018. [CrossRef]

11. Apte, J.S.; Brauer, M.; Cohen, A.J.; Ezzati, M.; Pope, I.C.A. Ambient PM2.5 reduces global and regional life expectancy. Environ. Sci. Technol. Lett. 2018, 5, 546-551. [CrossRef]

12. Lin, Y.; Bahreini, R.; Lee, S.-B.; Bae, G.-N.; Jung, H. Correlations of PM metrics with human respiratory system deposited PM mass determined from ambient particle size distributions and effective densities. Aerosol Sci. Technol. 2019, 54, 262-276. [CrossRef]

13. Bontempi, E. First data analysis about possible COVID-19 virus airborne diffusion due to air particulate matter (PM): The case of Lombardy (Italy). Environ. Res. 2020, 186, 109639. [CrossRef] [PubMed]

14. Bontempi, E. The Europe second wave of COVID-19 infection and the Italy "strange" situation. Environ. Res. 2021, 193, 110476. [CrossRef]

15. Bontempi, E.; Vergalli, S.; Squazzoni, F. Understanding COVID-19 diffusion requires an interdisciplinary, multi-dimensional approach. Environ. Res. 2020, 188, 109814. [CrossRef] [PubMed]

16. Bontempi, E. Commercial exchanges instead of air pollution as possible origin of COVID-19 initial diffusion phase in Italy: More efforts are necessary to address interdisciplinary research. Environ. Res. 2020, 188, 109775. [CrossRef]

17. Anand, U.; Cabreros, C.; Mal, J.; Ballesteros, F.; Sillanpää, M.; Tripathi, V.; Bontempi, E. Novel coronavirus disease 2019 (COVID19) pandemic: From transmission to control with an interdisciplinary vision. Environ. Res. 2021, 197, 111126. [CrossRef] [PubMed]

18. Shabnam, N.; Oh, J.; Park, S.; Kim, H. Impact of particulate matter on primary leaves of Vigna radiata (L.) R. Wilczek. Ecotoxicol. Environ. Saf. 2021, 212, 111965. [CrossRef] [PubMed]

19. Zanoletti, A.; Bilo, F.; Borgese, L.; Depero, L.E.; Fahimi, A.; Ponti, J.; Valsesia, A.; La Spina, R.; Montini, T.; Bontempi, E. SUNSPACE, A porous material to reduce air particulate matter (PM). Front. Chem. 2018, 6, 534. [CrossRef]

20. Cornelio, A.; Zanoletti, A.; Federici, S.; Depero, L.E.; Bontempi, E. Porous materials derived from industrial by-products for titanium dioxide nanoparticles capture. Appl. Sci. 2020, 10, 8086. [CrossRef]

21. Kasina, M.; Kajdas, B.; Michalik, M. The leaching potential of sewage sludge and municipal waste incineration ashes in terms of landfill safety and potential reuse. Sci. Total. Environ. 2021, 791, 148313. [CrossRef]

22. Bontempi, E.; Sorrentino, G.; Zanoletti, A.; Alessandri, I.; Depero, L.; Caneschi, A. Sustainable materials and their contribution to the sustainable development goals (SDGs): A critical review based on an Italian example. Molecules 2021, 26, 1407. [CrossRef]

23. Zanoletti, A.; Bilo, F.; Depero, L.E.; Zappa, D.; Bontempi, E. The first sustainable material designed for air particulate matter capture: An introduction to Azure Chemistry. J. Environ. Manag. 2018, 218, 355-362. [CrossRef]

24. Rodella, N.; Bosio, A.; Dalipi, R.; Zacco, A.; Borgese, L.; Depero, L.E.; Bontempi, E. Waste silica sources as heavy metal stabilizers for municipal solid waste incineration fly ash. Arab. J. Chem. 2017, 10, S3676-S3681. [CrossRef]

25. Panjehpour, M.; Abdullah, A.; Ali, A.; Demirboga, R. A review for characterization of silica fume and its effects on concrete properties. Int. J. Sustain. Constr. Eng. Technol. 2011, 2, 1-7.

26. Šyc, M.; Simon, F.G.; Hykš, J.; Braga, R.; Biganzoli, L.; Costa, G.; Funari, V.; Grosso, M. Metal recovery from incineration bottom ash: State-of-the-art and recent developments. J. Hazard. Mater. 2020, 393, 122433. [CrossRef]

27. Assi, A.; Bilo, F.; Federici, S.; Zacco, A.; Depero, L.E.; Bontempi, E. Bottom ash derived from municipal solid waste and sewage sludge co-incineration: First results about characterization and reuse. Waste Manag. 2020, 116, 147-156. [CrossRef]

28. Clavier, K.A.; Paris, J.M.; Ferraro, C.C.; Bueno, E.T.; Tibbetts, C.M.; Townsend, T.G. Washed waste incineration bottom ash as a raw ingredient in cement production: Implications for lab-scale clinker behavior. Resour. Conserv. Recycl. 2021, $169,105513$. [CrossRef]

29. Assi, A.; Bilo, F.; Zanoletti, A.; Ponti, J.; Valsesia, A.; La Spina, R.; Zacco, A.; Bontempi, E. Zero-waste approach in municipal solid waste incineration: Reuse of bottom ash to stabilize fly ash. J. Clean. Prod. 2020, 245, 118779. [CrossRef]

30. Zhang, H.Y.; Zheng, Y.; Hu, H.T.; Qi, J.Y. Use of municipal solid waste incineration bottom ash in adsorption of heavy metals. Key Eng. Mater. 2011, 474-476, 1099-1102. [CrossRef]

31. Granta Design Cambridge Engineering Selector (CES) Software 2019; Granta Design Ltd.: Cambridge, UK, 2019.

32. Us-Epa Method 3052-Microwave Assisted Acid Digestion of Siliceous and Organically Based Matrices; United States Environmental Protection Agency: Washington, DC, USA, 1996. 
33. Kasaniya, M.; Thomas, M.D.; Moffatt, E.G. Pozzolanic reactivity of natural pozzolans, ground glasses and coal bottom ashes and implication of their incorporation on the chloride permeability of concrete. Cem. Concr. Res. 2021, 139, 106259. [CrossRef]

34. Bontempi, E. A new approach for evaluating the sustainability of raw materials substitution based on embodied energy and the $\mathrm{CO}_{2}$ footprint. J. Clean. Prod. 2017, 162, 162-169. [CrossRef]

35. Fahimi, A.; Federici, S.; Depero, L.E.; Valentim, B.; Vassura, I.; Ceruti, F.; Cutaia, L.; Bontempi, E. Evaluation of the sustainability of technologies to recover phosphorus from sewage sludge ash based on embodied energy and $\mathrm{CO}_{2}$ footprint. J. Clean. Prod. 2021, 289, 125762. [CrossRef]

36. Ducoli, S.; Zacco, A.; Bontempi, E. Incineration of sewage sludge and recovery of residue ash as building material: A valuable option as a consequence of the COVID-19 pandemic. J. Environ. Manag. 2021, 282, 111966. [CrossRef]

37. Bontempi, E. Raw Materials Substitution Sustainability; Springer Briefs in Applied Science and Technology; Springer International Publishing: Berlin/Heidelberg, Germany, 2017.

38. Benassi, L.; Pasquali, M.; Zanoletti, A.; Dalipi, R.; Borgese, L.; Depero, L.E.; Vassura, I.; Quina, M.; Bontempi, E. Chemical stabilization of municipal solid waste incineration fly ash without any commercial chemicals: First pilot-plant scaling up. ACS Sustain. Chem. Eng. 2016, 4, 5561-5569. [CrossRef]

39. Assi, A.; Bilo, F.; Zanoletti, A.; Ducoli, S.; Ramorino, G.; Gobetti, A.; Zacco, A.; Federici, S.; Depero, L.E.; Bontempi, E. A Circular Economy Virtuous Example-Use of a Stabilized Waste Material Instead of Calcite to Produce Sustainable Composites. Appl. Sci. 2020, 10, 754. [CrossRef]

40. Bosio, A.; Rodella, N.; Gianoncelli, A.; Zacco, A.; Borgese, L.; Depero, L.E.; Bingham, P.; Bontempi, E. A new method to inertize incinerator toxic fly ash with silica from rice husk ash. Environ. Chem. Lett. 2013, 11, 329-333. [CrossRef]

41. Assi, A.; Federici, S.; Bilo, F.; Zacco, A.; Depero, L.E.; Bontempi, E. Increased sustainability of carbon dioxide mineral sequestration by a technology involving fly ash stabilization. Materials 2019, 12, 2714. [CrossRef]

42. Zanoletti, A.; Vassura, I.; Venturini, E.; Monai, M.; Montini, T.; Federici, S.; Zacco, A.; Treccani, L.; Bontempi, E. A new porous hybrid material derived from silica fume and alginate for sustainable pollutants reduction. Front. Chem. 2018, 6, 60. [CrossRef]

43. Assi, A.; Bilo, F.; Zanoletti, A.; Ponti, J.; Valsesia, A.; La Spina, R.; Depero, L.E.; Bontempi, E. Review of the reuse possibilities concerning ash residues from thermal process in a medium-sized urban system in northern Italy. Sustainability 2020, $12,4193$. [CrossRef]

44. Obe, R.K.D.; de Brito, J.; Lynn, C.J.; Silva, R.V. Sustainable Construction Materials: Municipal Incinerated Bottom Ash; Elsevier Ltd.: Amsterdam, The Netherlands, 2018.

45. Cheriaf, M.; Cavalante Rocha, J.; Péra, J. Pozzolanic properties of pulverized coal combustion bottom ash. Cem. Concr. Res. 1999, 29, 1387-1391. [CrossRef] 